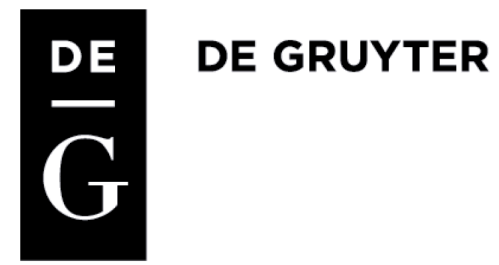

Lucyna Błażejczyk-Majka, Roman Macyra (Adam Mickiewicz University, Poznań)

\title{
FINANCIAL CRIME IN SOCIALIST POLAND AND ITS CAUSES IN THE LIGHT OF POLISH CENTRAL STATISTICAL OFFICE (GUS) STATISTICS
}

It might seem natural to think that the socialist model of the economy, and a reality where collective property prevailed, eliminated the problem of financial crime. But did it really? This paper, which presents the scale of this type of crime as reflected by GUS (Polish Central Statistical Office) statistics, is an attempt at answering this question. At the same time we would like to present the "3 Cs" model (circumstances, character, chance), in which all the "C" factors occurred simultaneously, but on each occasion each of these had a different impact on the particular criminal act.

Keywords: financial crime, statistics, GUS, socialist economy, "3 Cs" model.

doi:10.1515/sho-2016-0002

\section{INTRODUCTION}

Every type of crime usually evokes negative associations. It seems obvious, then, that this statement is not typically subject to any methodological debate. However, this approach in the case of financial crime requires more caution, as this type of crime reflected all the imperfections of the market, the state and the citizens. It reflected the structural and functional weakness of the state (regardless of its economic model and political system), which created circumstances (the first of the " $3 \mathrm{Cs}$ ") exploited by the human nature. At the same time, one has to take into consideration the political context, which (even by understanding the importance of time) allows one to better understand the complexity and the interdependence of the social, political, cultural and economic aspects - aspects which, in fact, for most of us are the defining features of everyday life. It is the weakness 
of the market and/or the state that helped the chances (the second of the "3 Cs"), which people created and/or took, and which directly influenced the scope and the scale of this type of crime. Finally, it is the individual, influenced by their personality, or character (the third of the 3 " $\mathrm{Cs}$ "), that commits the crime, either acting independently or in a group. Therefore, it can be assumed that what determined the causes, the scope and the scale of financial crime were, first, individuals and their personalities, second, their attitude to the economy, and third, the functionality and utility of the economic relations as perceived by these individuals.

Without doubt, financial crime, determined by the imperfections of the state and the market, developed differently in a market economy and in a state-controlled economy. The prevalent character of property might have played an important role, and any attempt to discuss the problem still encounters many obstacles. They result mainly from the analysis applied to the period of socialist Poland, which was accompanied by the systemic transformation occurring after the year 1944 [Tymiński M. 2002: 100]. This problem was the subject of numerous analyses and some authors even attributed the rise in financial crime to the systemic transformation itself [Majchrzak I. 1965: 24; Pawełko W. 1971: 45; Świda W. 1960: 21]. Also of some importance was the fact that the economic model implemented in socialist Poland never achieved market balance throughout its entire existence. In this aspect, the key problem for our analysis is defining the moment from which financial crime stopped being only the subject of legal debates and began to be perceived in a broader - economic, social and cultural - aspect as well [Marecki J. 1962: 57]. This distinction affects the definitions of financial crime, of which there are several [e.g. Cyprian T. 1960: 39; Górniok O. 1985: 10; Pawełko W. 1971: 16, 20]. For the purpose of this analysis, financial crime includes all actions which violated the legally regulated economic relations, regardless of the criminals' motivations and also regardless of the types of property existing in a given political system and economic model. This interpretation will probably allow us to avoid "explaining" the political and legal nature of some types of economic crime by political criteria, which could even lead to justifying some of them. The legal and moral principles in operation should, on the one hand, be the guide when making social choices, but on the other, provide at least some relative comparability with similar abnormalities present in the market economy.

An attempt to explain the nature and scope of financial crime in the socialist economic conditions in Poland according to the "3 Cs" model was 
preceded with quantitative analysis of data concerning this type of crime, maintained in the yearbooks of the Polish Main Statistical Office for the years 1955-1985. ${ }^{1}$ The aim of this paper is to verify the hypothesis that in the socialist conditions, the state created negative circumstances and, as a result, opportunities for committing crimes against the economy by groups or individuals, while staying neutral when assessing human nature/character of those who decided to commit the crimes, but also of the passive, often silent witnesses of these actions.

\section{FINANCIAL CRIME AND THE LEGISLATION OF SOCIALIST POLAND}

The statistical division of crime in socialist Poland depends on the legal provisions that were in force at that time. Until 1970, the criminal code of 1932 was in force [Journal of Laws 1932, no. 60, item, 571], but financial crime was not defined as a separate category there. However, chapter 39 of the code defined crimes against property, chapter 40 - crimes to the harm of creditors, and chapter 41 - clerical offenses. Still, the provisions of the code had been drafted in the reality of market economy, which essentially did not correspond with the new economic system. However, on that basis, statistical yearbooks from 1957 on distinguished between theft of private and collective property. Furthermore, crimes concerning fraud, handling stolen goods and speculation were included in separate categories. Clerical ${ }^{2}$, fiscal and currency-related offenses were also mentioned.

The new criminal code was adopted much later, in December 1969, and came into force on January 1, 1970. [Journal of Laws 1969, no. 13, item 94] It included the following types of crime in the category of crimes against collective property: seizure, appropriation, bold theft, breaking and entering, robbery and armed robbery. There was a separate legal category

${ }^{1}$ In the text we use the following terms to define the economic model in socialist Poland: the socialist model, state-controlled economy. Furthermore, limiting oneself to this source of data entails some simplification, as it would be necessary to also use data maintained by the Citizens' Militia Main Headquarters, courts, and the Supreme Audits Office.

${ }^{2}$ Clerical offenses included: negligence, embezzlement, wastefulness and bribery. 
for financial crime, which included speculation and causing shortages. ${ }^{3}$ Fiscal, currency-related and customs-related crimes were a separate category, including the forgery of money, securities, trademarks or measuring apparatus. Finally, the code defined documents-related crime: forging documents and attestation of an untruth by a public officer.

It would be much easier to point to actions related to financial crime than to provide an all-encompassing definition of this type of crime which would include all aspects of economic activity without defining the subject exposed to its negative consequences and those subjects inflicting them. Based on the aforementioned legal acts, though, we can say that the legal understanding of financial crime did develop somewhat in the conditions of state-controlled economy. Namely, there was a new type of financial crime related to the introduction of a new economic model after the war, different from those which, although not completely absent in the new system, were related to the previous one, i.e. the "classic" customs and fiscal crimes. It was assumed that in the new system, this category of crime should essentially disappear, as according to the constitution of July 22, 1952, section 77:

Every Polish citizen is obliged to protect collective property and strengthen it as a firm foundation of the state's development and a source of wealth and power for the Homeland. Those who try to sabotage, commit diversion, harm or attack collective property are to be punished with utmost severity [Journal of Laws, no. 33, item 232].

We must note though that there was a significant difference between "collective property", perceived as national property or group property of cooperative means of production, and private property, which dominated previously. The ideological assumptions concerning this type of property seem to be beyond any emotional or rational understanding for a significant part of society. For most people, this was probably a completely abstract idea, though we will never find out for sure. In this context, after all, it would be justified to talk about "no man's property" and a social permission to attack it [Pawełko W. 1971: 390-391]. Leaving society in a position of co-owners (even if just formally) of the national property, and at the same time obliging it to comply with laws resulting from professional dependencies, led to individual blurring of those distinctions in the situation of increasing shortages on the market.

3 See: e.g. Sections 127, 132-135, 199-246, which regulated penal sanctions for specific types of economic crime. 


\section{FINANCIAL CRIME AS AN ECONOMIC AND SOCIAL CATEGORY}

In the systemic model operating in socialist Poland, the primary sphere where financial crimes were committed was the area where the social and the private sectors met [Lernell L. 1965: 15]. Though it could be limited to the organization and functioning of companies', this might be too much of an overgeneralisation. Nepotism, cronyism, fraud and corruption can be included in the catalog of various types of abnormalities that were labeled "financial crimes committed by staff". These were surely to some extent the result of systemic conditions, but not only that [Majchrzak I. 1965: 297]. The other side of the story was the effect of this type of crime on the day-to-day economic activities. From this point of view, financial crime is not only a legal term, it is something more. It has its own economic, social and cultural context.

Since in the system of the time both means of production and products were for a large part public property - cooperative or national, the problem was mostly perceived in the categories of acting against collective property [Lernell L. 1965: 99-105; Pawełko W. 1971: 13]. However, if we reverse the point of analysis and assume that the economy - as a collective property of the society - was the "victim", with its lack of economic efficiency resulting from a connection between the attitudes of those employed there and the systemic weaknesses, then any action which was against the law and aimed at limiting the efficiency of the means of production available at a given point can be considered a crime. This perspective of analyzing the problem poses an open question as to the assessment of economic decisions taken by the political and economic authorities of the time. Without doubt, the assumptions of the system and the organization of the economy in the years 1944-1989 generated a certain way of adaptation among its participants [Tymiński M. 2002: 100]. A thesis of Michał Kalecki who thought that "the roots of financial crime (...) are found at the stage of development where the main focus is placed on quick increase in production" was an early reaction to this type of phenomena [Kalecki M. 1962: 73].

Unfortunately, the statistical data available are very inconsistent and often fragmentary and were collected using various methodologies, and therefore it is not possible to classify financial crimes according to the stage of the production process. Thus, we cannot separate those crimes committed at the "trade" stage from those committed at the "production" 
stage [Lernell L. 1965: 25-51]. A more detailed classification of the crimes behind these two categories would allow us to quantitatively define illegal acts such as: "saving up" on fuels, resources etc., "non-compliance with technological processes" resulting in low quality of products (often this was due to insufficient skills of employees), but also: falsifying measurements, or understating or overstating the standard/class of the product (especially visible in trade in agricultural products). A separate category were financial crimes "directly diminishing the collective property fund", with a division into traditional and non-traditional (implicit) fraud, including the following: excessively increasing prices, performing odd jobs, and price speculation [Lernell L. 1965: 55-69]. Apart from the division into crimes committed during the production and trade stages, there was also a division based on the perpetrator and the circumstances conducive to a given type of illegal act [Majchrzak I. 1965: 297]. In general, there was a prevalent belief among the researchers of this problem, that more opportunities to detect crimes existed in trade than in production. This resulted from the fact that in the production process there were not only quantitative but also qualitative changes. This in turn required knowledge on the norms of material use and the quality of the means of production used [Marecki J. 1962: 59]. Apart from the division into crimes committed during the production and trade stages, there was also a division based on the perpetrator and the circumstances conducive to a given type of illegal act [Majchrzak I. 1965: 297]. Almost all these categories were accompanied by the internal quantitative division of collective property appropriation into small, medium and large.

Concluding this part, we would like to point to the fact that both the socio-economic and the legal side of analyzing financial crime did not lead to the emergence of a single consistent definition back then [Cyprian T. 1958: 24-28]. Therefore, we consider financial crime to include acts in violation of the legally regulated economic relations, regardless of the form of property existing in a given political system and economic model. Using this definition, we can avoid the need to specify the meanings behind the terms "economic order" or the "right course of the economic life", which were commonly used at the time. At the same time, this definition does imply judgment of this type of crime and does not "encourage" the participants of the economic life to commit it in any way. More importantly, this definition allows us to avoid the "political interpretation" of the character of some types of financial crime, i.e. looking at them based on political criteria and thus justifying some of them. It is the legal and moral prin- 
ciples in operation that should guide the social choices and provide some relative comparability with similar abnormalities present in the market economy.

\section{RESEARCH MATERIAL}

Statistical data which are the basis for our quantitative description of financial crime in socialist Poland were maintained by GUS and published annually in statistical yearbooks for the years 1957-1997. Special publications released on anniversaries of socialist Poland were also used. Essentially, the material concerning financial crime was presented in two groups: 1. the statistics of the crimes committed, and 2. the number of convictions for specific crimes in a given year. We would like to emphasize that in some periods there were some inconsistencies in this data resulting from the grouping methodology, lack or disappearance of some categories of crime, and also quantitative variance of the data for particular years published in subsequent editions of these yearbooks. Regardless of the reasons behind these differences, we decided that using them would enable us to perform at least a preliminary assessment of the scale of the problem over the three decades. Based on these comparisons, we attempted to create a statistical series of data on financial crimes committed in the years 1955-1985.

The research subject defined this way entails three basic hazards. The first one is related to statistical elusiveness and incommensurability. The problem was pointed out e.g. by Oktawia Górniok, who wrote that " (...) in GUS statistics the volumes of shortages, natural losses and material losses were all treated jointly" [Górniok O. 1986: 15]. Therefore it is hard to find variables whose statistical series cover the whole period studied, which resulted e.g. from changes in legislation and from different ways of categorizing crimes. The second hazard is related to a number of unknown financial crimes, which were not recorded in any way. The informal, parallel or simply black market was an inseparable part of the economy back then, and "the basic part of this activity can, or even has to, take place within companies" [Chłopcki J., Firlit E. 1987: 6-7]. ${ }^{4}$ The third hazard is relat-

\footnotetext{
${ }^{4}$ No reliable data exist; however, it is estimated that the black market in this period reached even $75-80 \%$ (reference to the literature), therefore we assume, despite this uncer-
} 
ed to the choice of variables explaining the relationship between financial crime and economic and social factors. Statistical analysis of the number of financial crimes and their categories in the years 1955-1985 concerned an economy whose condition changed over this period of time [Majchrzak I. 1965: 305-306]. Furthermore, the choice of explanatory variables - personality, human nature, opportunity, circumstances - can definitely be considered subjective. It seems though that the data selected are so versatile that in the conditions of constant changes in our environment and in ourselves, their analysis will enable specifying more detailed factors and circumstances accompanying financial crime in the period discussed.

\section{FINANCIAL CRIME IN SOCIALIST POLAND: RESEARCH METHODOLOGY}

The starting point for the quantitative description of economic crime in socialist Poland is the picture of crime in general and the distinction between theft of individual and social property. Time frameworks for these variables were built based on two categories of tables: "Crimes reported to the Citizens' Militia according to types" and "Crimes confirmed in pretrial proceedings, according the types of crime", which were published in statistical yearbooks for the years 1955-1970 and 1971-1985, respectively. This allowed to develop time frameworks which were the foundation for generating an accumulated area graph, showing the scale of these two types of crime against the general level of crime for the period analyzed (Graph 1).

The general conclusion is that financial crime dominated within the general scale of crime in socialist Poland. A detailed analysis indicates that although in the year 1955 the number of crimes reported by law enforcement agencies reached almost 340,000, and a systematic increase was observed until the end of 1957, in the 1960s there were a lot of fluctuations, and the years 1966 and 1970 can be considered the peaks in this period of time. On the other hand, the 1970s presented two fundamentally different faces: first, until 1975, the number of crimes varied (despite increases and decreases, there were around 300,000 of crimes a year), while in the sec-

tainty, that this value remained approximately constant throughout the whole studied period. 
Graph 1. The number of crimes in the years 1955-1985

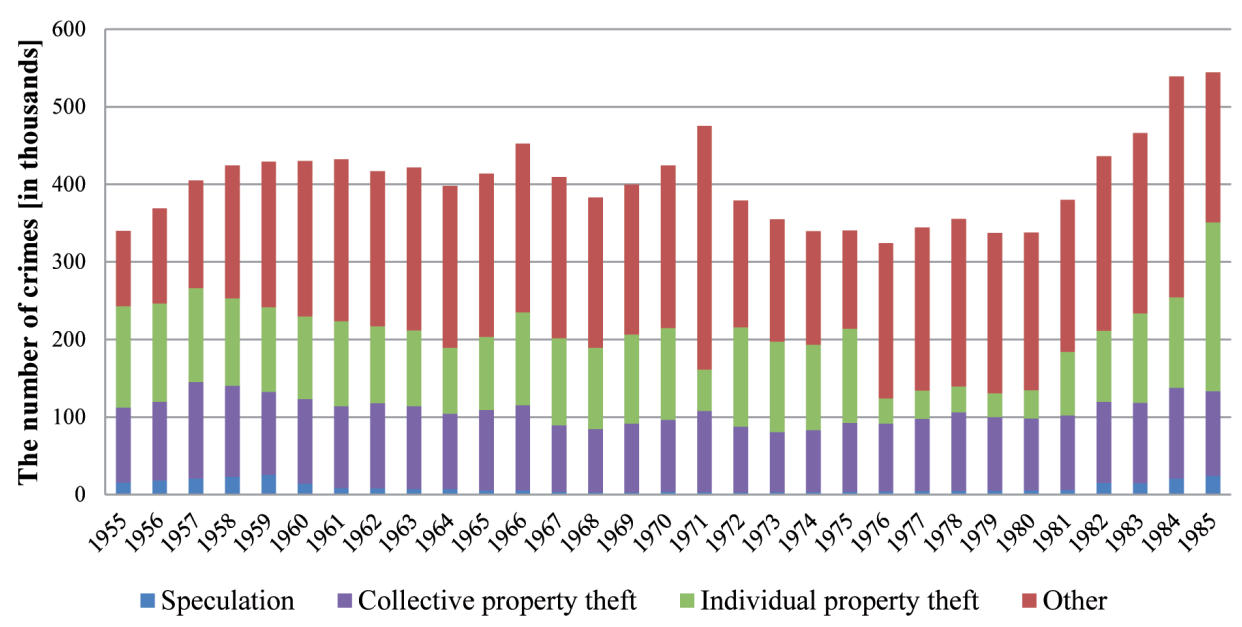

Source: own work. Compare: GUS data for the years 1955-1986.

ond half, until 1980, there was a clear decrease in the number of crimes down to around 200,000-220,000 per year. Only in the last period analyzed was a significant increase observed - in 1985, over 540,000 crimes were reported. ${ }^{5}$ Throughout the whole period, the number of crimes against collective property was characteristically much more stable compared with the number of crimes in general or the number of crimes against individual property. In the first period studied, the number of thefts of collective property reported to the Citizen's Militia was almost 96,000, i.e. around $28 \%$ of all crimes. In the next decade, this number fluctuated from 78,000 (1973) to 117,000 (1985), and from around 21\% (1967) to 31\% (1957) of total crime. Crimes related to speculation accounted for a much smaller percentage of the total number of crimes. They contributed from around $1 \%$ (in the years 1965-1979) to almost $6 \%$ in the beginning and at the end of the period studied. In absolute numbers, they reached 25,000 of reports at most (1959).

In order to describe financial crime in more detail we need to refer to the data published after the new criminal code had been introduced. From

${ }^{5}$ A more detailed analysis of quantitative changes would require taking dependent and independent variables into consideration. E.g. it would be necessary to consider the scale of amnesties granted by the authorities back then. It is enough to show that for the period analyzed, amnesties were granted on: April 15, 1956, July 22, 1964, July 15, 1969, July 15, 1974, July 15, 1979, July 22, 1983 and July 21, 1984 (amnesty act of July 19, 1977 mainly applied to the participants of the so-called Radom incidents). 
Graph 2. The number of financial crimes in the years 1970-1985

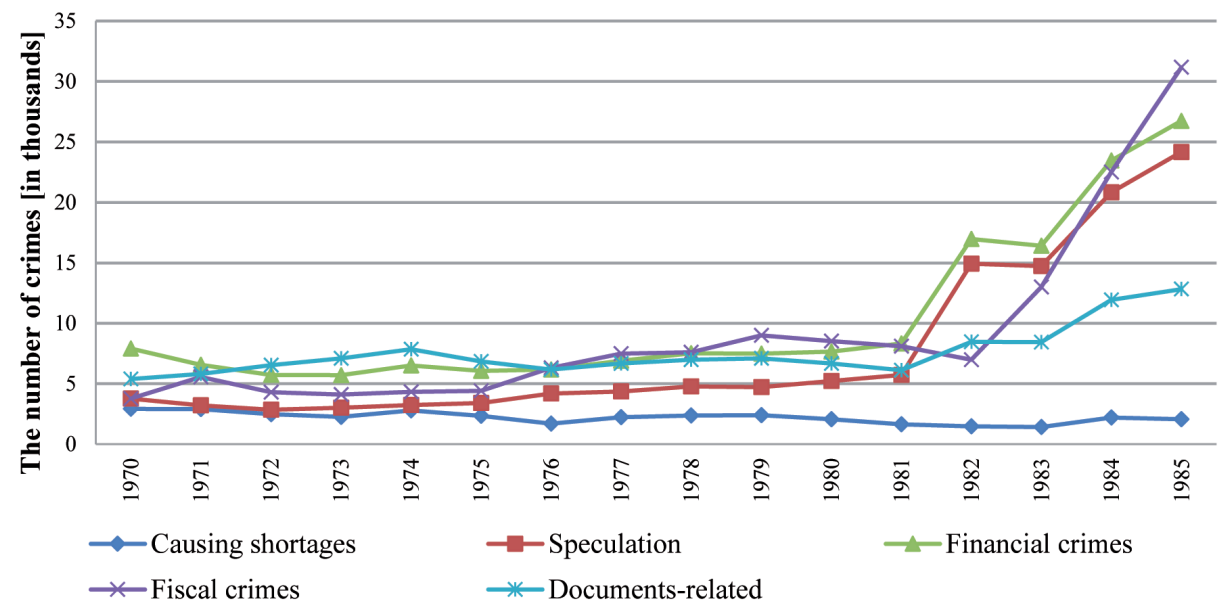

Source: own work. Compare: GUS data for the years 1969-1986.

1970, GUS statistics showed a separate category for financial crime, which mainly included causing shortages and speculation.

The change of criminal code in 1970, regardless of its substantial and political causes, expanded the scope of possibilities for interpreting the problem of financial crime and included new, legally sanctioned categories such as fiscal and documents-related crimes. Based on data for the years 1970-1985 (Graph 2) it can be observed that none of the aforementioned types of crime exceeded 10,000 cases annually in the 1970s. The numbers increased dramatically, apart from those concerning shortage, in the 1980s. After 1980, the number of fiscal crimes increased the most. The type most strongly correlated with the total number of financial crimes were crimes related to speculation.

The number of financial crimes, treated as a legal category based on the new criminal code, accounted for just $2 \%$ of all proceedings after 1970. Only in the last years of the period studied this share increased to around $5 \%$. Theft of collective property accounted for much higher proportions, from $20 \%$ to $28 \%$ of the total number of proceedings launched throughout the studied period. We can tentatively assume that all weaknesses of the economy of shortages were evidenced by these data. Reported thefts of private properties showed a much larger rate of fluctuation. Their number started to increase dramatically after 1980, which could have resulted from many factors, such as the increased social awareness of the impor- 
Graph 3. The number of financial crimes as a social and economic category* in the years 1955-1985

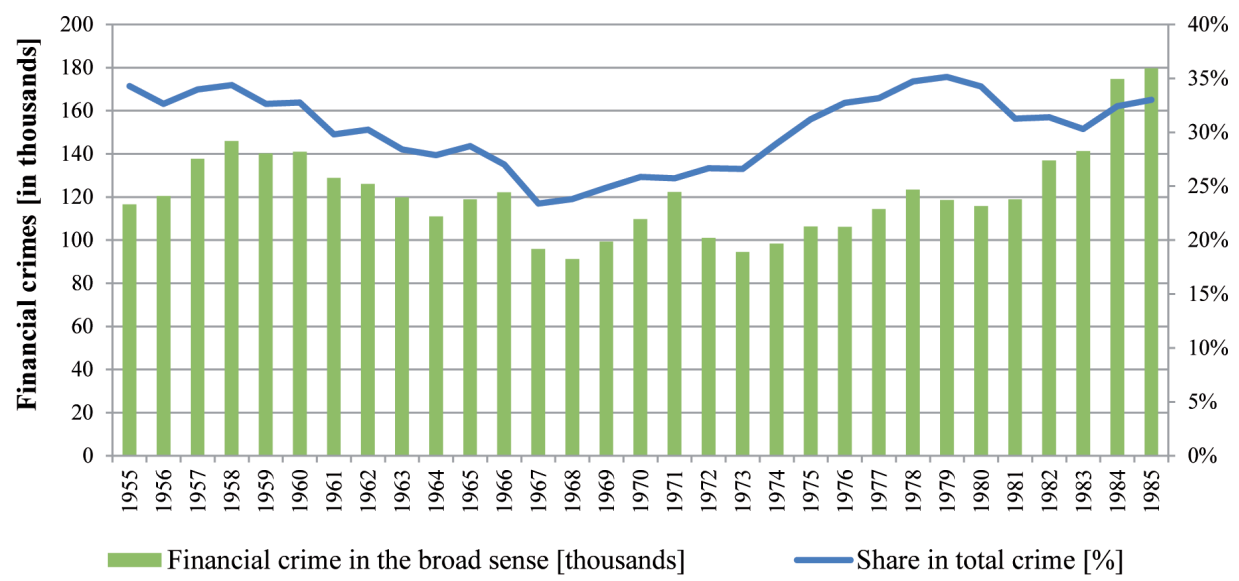

* 1955-1969: crimes against collective property + clerical offenses + fraud

* 1970-1985: crimes against collective property + financial crimes + documents-related crimes + fiscal crimes

Source: own calculations. Compare: GUS data for the years 1955-1986.

tance of private property, the civil awareness of victims who expected the authorities to react to the crime, and the even more difficult situation on the market, increasing shortages, and other factors which can be considered social, economic or cultural in nature. All that would require a separate analysis, and thus these problems are only signaled here.

As already mentioned, financial crime is not just a legal but also a social and economic category, not only causing a specific financial loss, but also affecting social relations and having an impact on building mutual trust or a sense of social justice. We assumed that crimes of causing shortages and speculation, as well as fiscal crimes, crimes against social property and documents-related crimes, all resulted in tangible and measurable loss of the value of national and private property. In the years 1955-1970, when these types of financial crime had not been defined as a separate legal category yet, clerical offenses were also included here, comprising crimes related to causing shortages and attestation of an untruth by a public officer, and all kinds of fraud related e.g. to the weight or quality of products (Graph 3).

The period with the lowest absolute level of financial crime in the social and economic understanding was late the 1960s, with numbers for the years 1967 and 1968 below 100,000 annually. In this period, they also repre- 
sented the lowest share in total crime, less than $25 \%$. From the early 1970 s, the number of financial crimes as a social and economic category regularly increased. After the year 1981, we can even say there was a rapid increase in the number of these crimes; this was a counter-reaction between the failure of market mechanisms and the authorities, and the weakness of the human nature among the representatives of various social strata back then. At that time, there was an absolute increase by 60,000 financial crime cases. At the same time, in the last years of the period studied, the total number of crimes also increased. The annual share of financial crimes in the social and economic understanding was the largest in 1979, accounting for $35 \%$ of the total number of pre-trial proceedings initiated.

While summarizing these data, one has to note that what mattered for the economy the most were the losses that these crimes caused. These can be observed in several aspect, and can be more or less measurable in terms of their financial, human and social impact. According to data from the Ministry of Justice, in the early 1960s losses resulting from financial crimes were around 700 million PLN per year [Lernell L. 1965: 82]. How uncertain similar estimates can be is evidenced by the results from roughly the same period, estimating losses in food trade alone at 2.5 billion PLN [Marecki J. 1962: 61]. Defining the scale of financial crime with the help of intuition and estimates was surely a characteristic feature of the 1960s, when crimes were very often detected owing to a coincidence. Let us leave this very interesting point open, though - as the problem does not only involve specific values, but also changes in the purchase power of money over time and stick to economic issues only.

\section{CONVICTIONS FOR FINANCIAL CRIME IN SOCIALIST POLAND: STATISTICS}

If there is a crime, there must be a criminal - however this criminal was not always convicted. The second group of statistical data published by GUS in relation to financial crime comprised the numbers of adults convicted for actions related to financial crime. A different method of analyzing crime is approaching it from the point of view of the perpetrator and their personality, i.e. the factors which could potentially affect their decision, such as age, gender, nationality, denomination, education, professional position, family and financial situation and, in extreme cases, also 
Graph 4. Adults convicted for crimes including crimes against collective property in the years 1955-1985

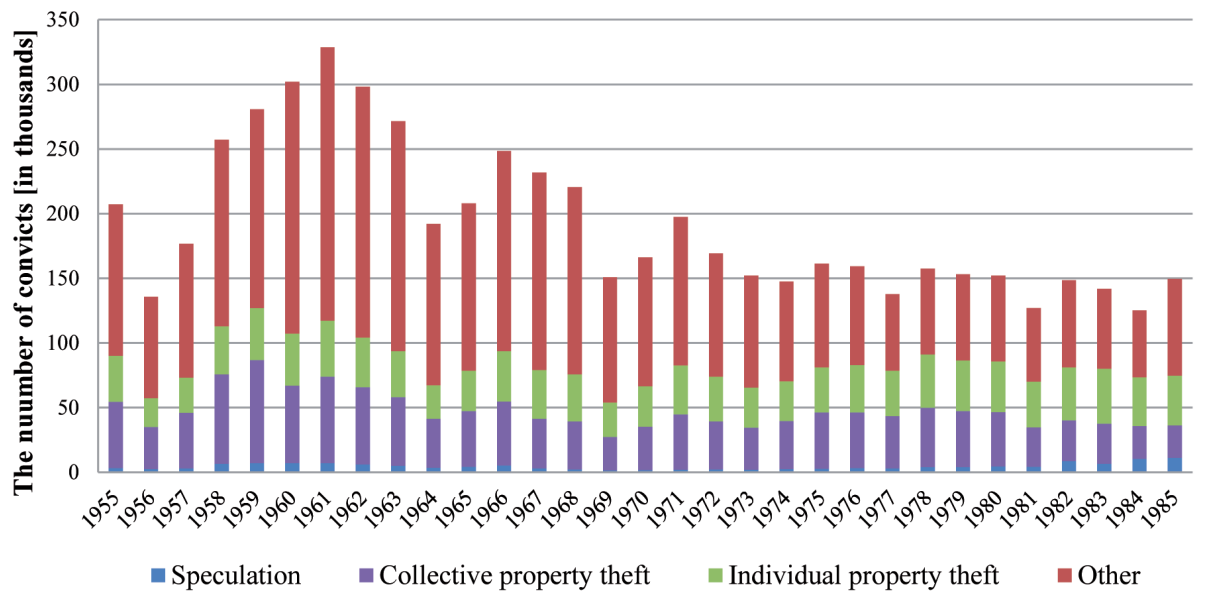

Source: own calculations. Compare: GUS data for the years 1955-1986.

possible recidivism (e.g. in 1969 these cases accounted for $29.7 \%$ of the total) [Pawełko W. 1971: 407]. In our analysis, we use this precise category: the number of convicts, i.e. those individuals that were put in front of a judge and sentenced - which required compliance with the rule of individual criminal liability. Social imagination was mostly kindled by scandalous crimes, though, where organized gangs - as was often revealed in criminal documentation and in analyses of the party assets - undertook organized attacks against collective property. Clerks and public officers were the main administrators of collective wealth, with varied levels of authority, and they were the ones who could commit these acts, or, very often without being aware of a criminal act, were accused of it, because the lack of specific provisions enabled to charge them with negligence. Furthermore, a new, highly creative group emerged in the socialist economy - termed "the criminal bourgeoisie" or "some employees of socialist institutions" - that skillfully acted on the junction of socialist and non-socialist sectors of the economy (Graph 4) [Narojek W. 1973: 36-37; Kalecki M. 1962: 73; Tymowski A. 1977: 25].

The number of convictions for financial crimes showed significant variation in some periods, which could be explained by political crises (e.g. years 1957-1961 after October 1956, the year 1971 after the events of December 1970), amnesty acts (years 1965-1966 after the amnesty act of 1964), and some local factors which greatly influenced the general numbers. The 
Graph 5. The number of adults sentenced to imprisonment in the years 1970-1985

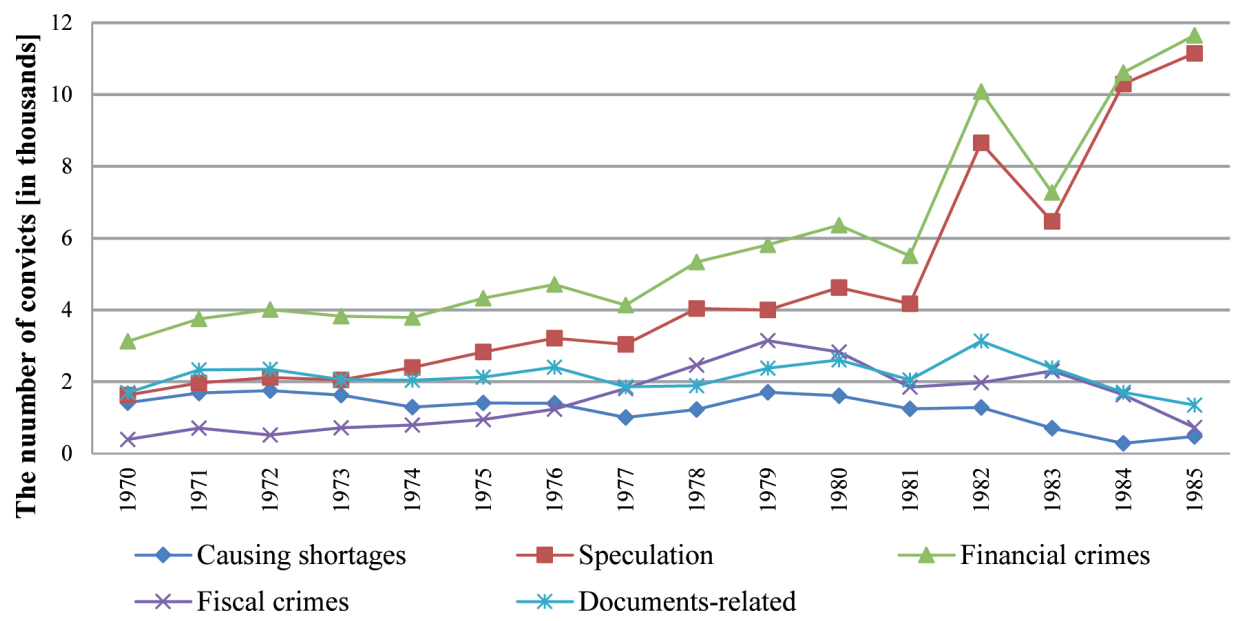

Source: own calculations. Compare: GUS data for the years 1969-1986.

biggest number of adults was convicted in 1961, reaching almost 330,000 adults sentenced to imprisonment. From this moment, the number of adults sentenced to prison annually decreased, with some fluctuations, to around 150,000 adults in 1973 - and then remained more or less constant until the end of the period analyzed. As opposed to the number of crimes reported to Citizens' Militia, there was no dramatic increase in the number of adults convicted in the first half of the 1980s.

However, if we differentiate between the number of adults convicted for stealing collective property and those convicted for stealing private property in our analysis, it turns out that the number was higher for the first group throughout the studied period. Exceptions occurred in the year 1969 and the 1980s, when the situation was opposite and, what is more, the number was relatively higher in the first period and gradually dropped in subsequent years. The number of convictions for crimes against collective property varied from almost 80,000 adults in 1959 to slightly more than 25,000 in 1985 . The number of convictions for stealing private property was characterized by a much higher stability. It has already been mentioned that GUS data on financial crime published after 1970 provide much more detail. They also included people convicted for fiscal and documents-related crimes, i.e. essentially those who individually completed their tax returns, and some groups of public officers (Graph 5). 
Graph 6. The number of adults convicted for financial crimes* in the years 1955-1985

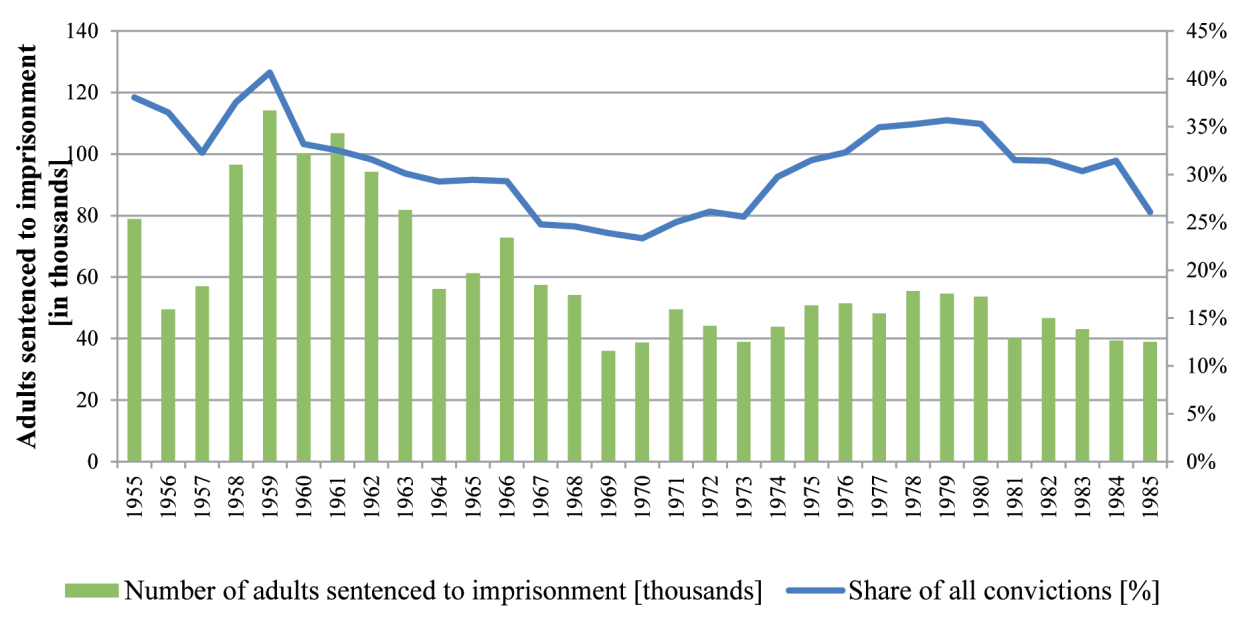

* 1955-1969: adults sentenced to imprisonment for crimes against collective property + clerical offenses + crimes to the harm of the economic interest of the state

* 1970-1985: adults convicted to imprisonment for crimes against collective property + financial crimes + documents-related crimes + fiscal crimes

Source: wn calculations. Compare: GUS data for the years 1955-1986.

The general observation is that after 1976, one could see a significant increase in the number of convictions for financial crimes, and the number of convictions for speculation is clearly correlated with this trend. Among all the categories of crimes, the number of those sentenced for this particular crime increased the fastest, by an average of 500 people per year. We can even formulate a preliminary thesis that the significant worsening of the quality of life from the mid-1970s, along with stimulated consumption, fostered - as external factors - the intensification of criminal activity. A more detailed analysis shows that the number of individuals sentenced to imprisonment for causing shortages or for documents-related crimes was around 2,000 adults in the whole period, and in the final years it even decreased. The numbers of adults convicted for fiscal crimes were slightly more dynamic. From 1979, they regularly increased, reaching 3,000, and then, a decrease was observed. However, one must remember that the number of convictions for financial crimes in the last year comprised less than $8 \%$ of all convictions for crimes punishable with imprisonment (Graph 6).

If we look more broadly at financial crime and label it as the sum of crimes against collective property, crimes to the harm of economic inter- 
est of the state, and clerical offenses, then it must be noted that the number of convictions for these crimes amounted to 80,000 adults in the year 1955, accounting for nearly $40 \%$ of the total number of convicted adults. After the year 1950, these numbers regularly decreased to a level below 40,000 people and $30 \%$ in the year 1969. After the change in legislation in the year 1970, the number of convictions for financial crimes in the social and economic understanding - despite a slightly different composition of categories comprising it - turned out to be at a similar level. Even though, throughout the whole 1970s, it did not exceed 60,000 people, the contribution in the total number of inmates grew, reaching in its peak $35 \%$ in the years 1977-1980. The early 1980s were characterized by a significant decrease in the share of convictions for financial crime in the total number of convictions, and a small decrease in absolute values. At this point we are trying to avoid specifying the factors affecting these values. Nonetheless, we would like to point e.g. to the functioning of the judiciary system, the efficiency of law enforcement agencies, the political attitudes towards this type of crime and the efficiency of defense teams in trials.

The quantitative description of financial crime in socialist Poland can be concluded with a presentation of the number of proceedings launched per one person sentenced to imprisonment. This was also prepared in relation to specific categories of crime. In the case of the problem at hand, it seems extremely important to assess the contribution of convictions for financial crimes in the total number of convictions in a given year. In order to do so, just like before, we analyzed the structure of convictions according to the type of crime committed and, in order to improve result comparability, included the same years as in the previous analysis of the structure of crimes (Graph 7).

The number of proceedings initiated per one conviction indicates the lowest efficiency in the proceedings in cases of theft of private property, almost throughout the studied period - with the exception of the year 1980. On the other hand, the number of proceedings launched in cases of theft of collective property per one person sentenced for this crime was higher than average until 1974, and only slightly lower in the years 19751981. After this period, it increased once again above the average, which was roughly one conviction per two initiated proceedings. Financial crime in the social and economic understanding, analyzed this way, oscillated around the average, so per one proceeding launched there was one "guilty" verdict throughout the whole period analyzed. The last year studied was the only exception here. 
Graph 7. The number of proceedings initiated per one conviction in the years 1955-1985

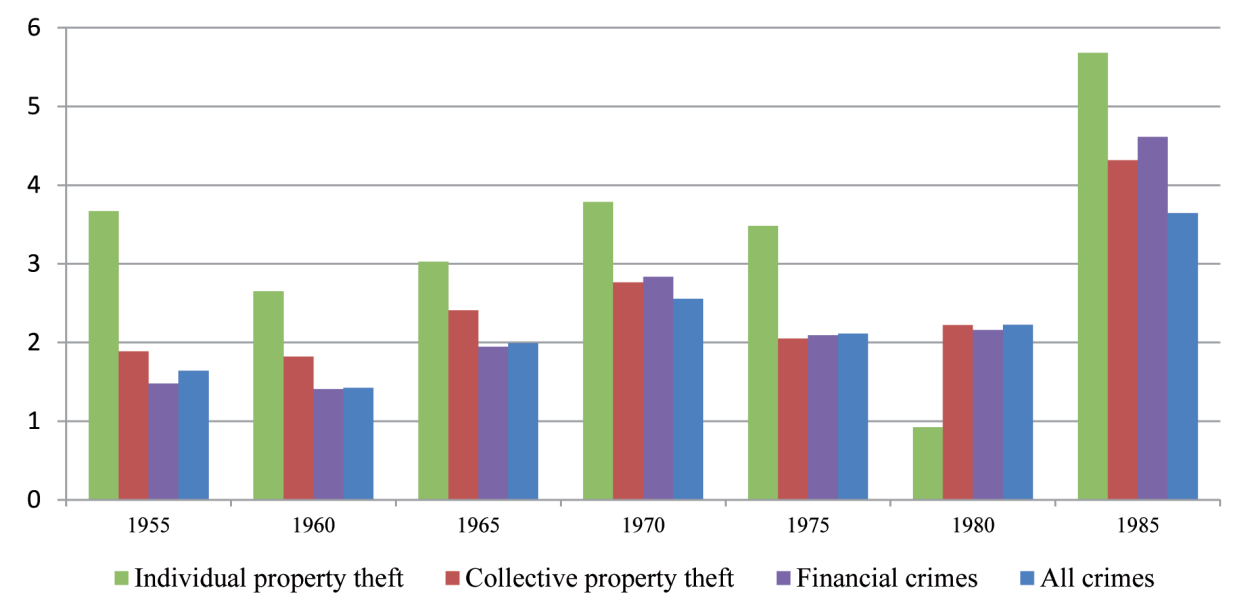

Source: own calculations. Compare: GUS data for the years 1955-1986.

\section{CAUSES OF FINANCIAL CRIME IN SOCIALIST POLAND}

We can never be absolutely sure as to the reasons behind financial crime, because behind every single case there was a different set of accidental and/or planned actions. Our proposal aims at limiting this uncontrollable number of factors to three fundamental "Cs": (1) circumstances - resulting from internal and external frameworks and institutional principles of the social, economic and political system; (2) chance - deliberately created or accidental situations conducive to committing a crime, and (3) character/human nature - shaped individually or by a group in a defined cultural space and in a system of ethical and moral norms. The new political and economic system which emerged after 1944 questioned the right to individual property and the whole legal system that sanctioned this tradition. ${ }^{6}$ This decision fundamentally changed the systemic

6 This process was distributed in time, but fundamentally, at the end of 1949, the dominant part of national property became the property of the state, regardless of the way it was internally defined. Acting on behalf of "historical justice", a number of changes was introduced, including (to name just a few): the nationalization of the industry, the decree on agricultural reform, the monetary system reform and the new constitution. 
foundations of the state, which, despite the war and the changes occurring at the time, did not undermine the right to property to such an extent (this was the new circumstance). We also believe that the scope of these changes was a signal, however unintended, for using opportunities arising in one's surroundings - direct (e.g. in the workplace) and indirect (e.g. shortages on the market) - for committing crimes in this aspect of economic relations. Furthermore, as the society read the signals from the authorities as incoherent and incongruent with the reality, this actually undermined the system of values of an individual and their social attitudes, which we consider a factor related to character/human nature (but not only that this process had already started evolving in the times of German occupation [Wyka K. 1984: 126-127].

In the context of the assumption we already know, stating that "financial crime is a function of the economic system" [Cyprian T. 1960: 34], the systemic change opened a whole new field of interpretation. The dominance of social property created new circumstances, doubling the losses resulting from an individual financial crime, which on the one hand affected end consumers - due to quantity, quality and price of goods - and on the other hand, undermined the value of social property - as a function of production, which manifested at the final stage in the inefficient use of production means and, consequently, in increasing shortages on the market. This constantly expanding gap was usually accompanied with illegal methods and actions aiming at eliminating it, which in time led to the emergence and development of an alternative economic system. Its basic feature was the dominance of market mechanisms, but with a simultaneous breach of the rules of the state-controlled economy. Several terms were coined to name the situation, including e.g. "the parallel economy" [Bednarski M. 1992: 27]. The aforementioned circumstances were an inspiration for attempting to present a simplified model of the economic cycle, and the various types of functional dependencies and interactions related to them, which created opportunities for the emergence of various situations and, thus, for crimes of a financial nature (Diagram 1).

Our proposal is an attempt to define a very complicated problem within a model, whose purpose is to show the conditions and the mechanism behind financial crime in the state-controlled economy using two circles and the dependencies occurring between them. The first circle comprises social and private property, with a clear disproportion in terms of size and value, which shows the basic assumptions of the new model of administration and constitutes the independent variable - the circumstance. The 
Diagram 1. Diagram of the economic cycle in socialist Poland

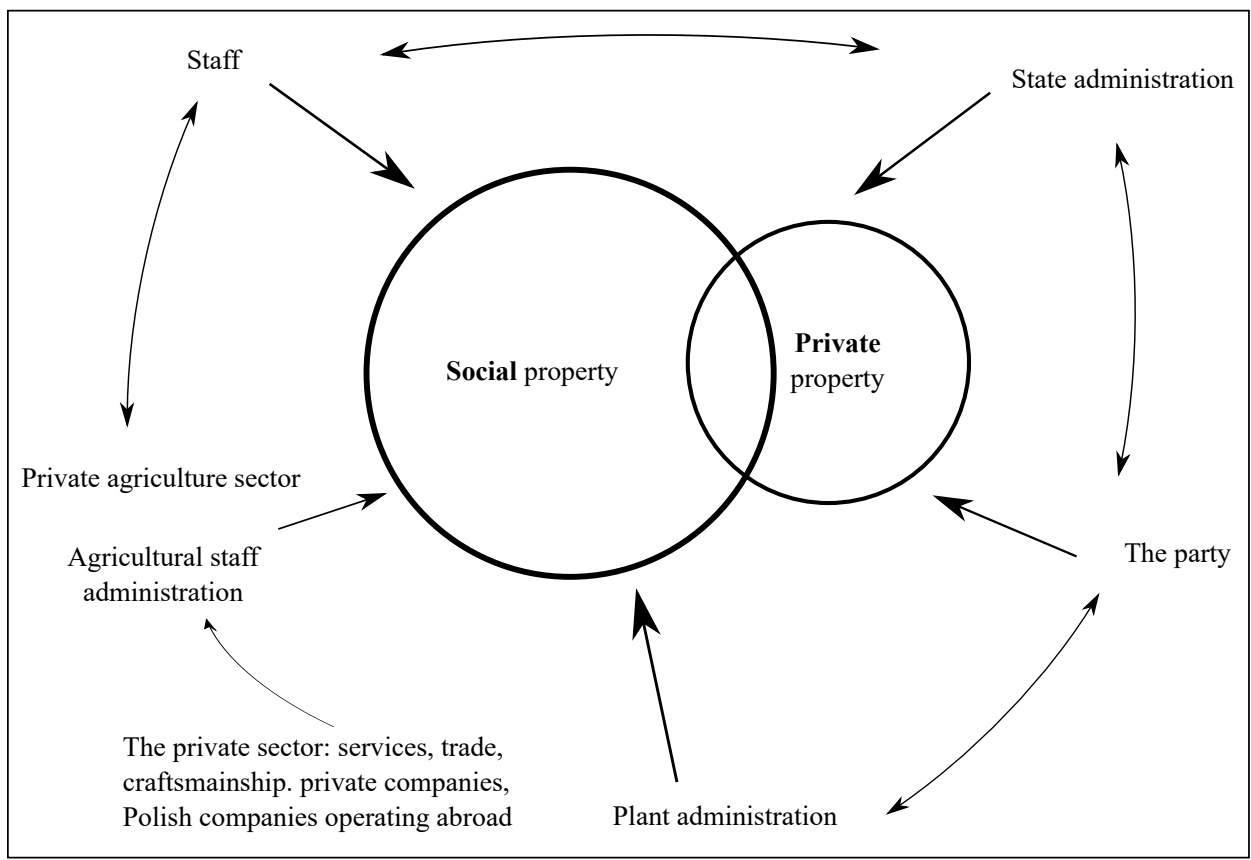

Source: own work.

second circle comprises a number of institutions participating in the activities in various specific sectors of the economy within the scope of their property status. This resulted in actions distinguished in accordance with chances that emerged on the connecting point in the exchanges between these subjects. The last circle, hidden in our diagram, was human nature/ character, which manifested in attitudes, choices and actions of specific individuals placed in the second circle. The economic model in place, where state property dominated, influenced the type and the scale of economic crime, which is well evidenced by statistical data concerning the structure of industrial property and employment (Graphs 8 and 9).

A comparison between these two structures points to the chances that the system created for committing financial crimes. It is hard to determine the validity of the thesis that seeing no real possibilities of changing the system, and seeing its systemic "flexibility", the society placed their aspirations and dreams in the financial aspect, and limited its pursuit of freedom or gave it up altogether. Thus, the society looked for opportunities or seized them, particularly since deliveries of goods for the state-controlled 
Graph 8 . The property structure of industrial plants in the years 1960-1985

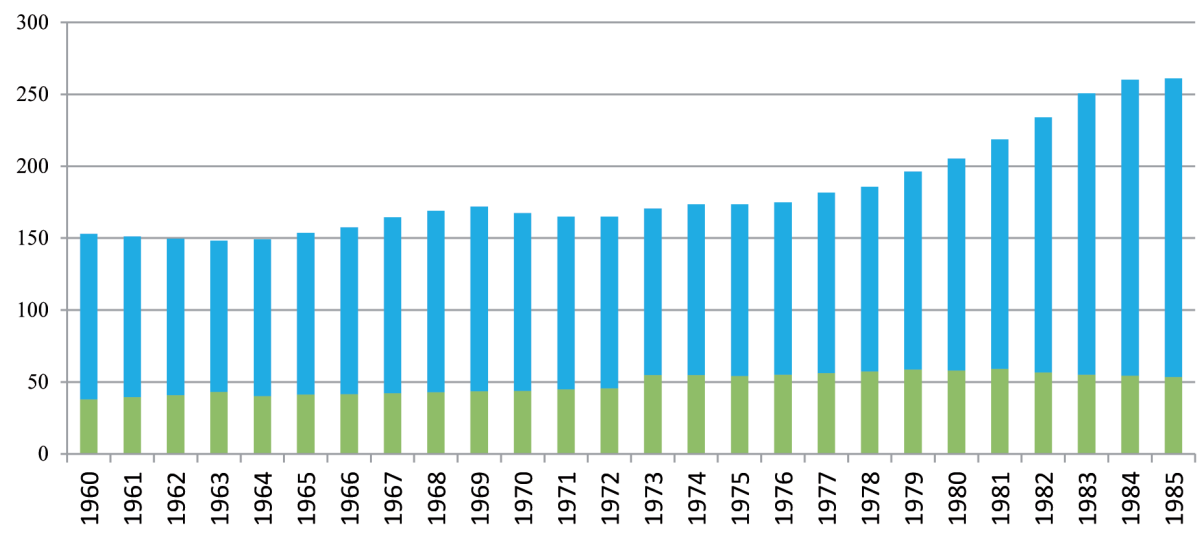

= State-controlled plants [thousands] Non-state-controlled plants [thousands]

Source: own calculations. Compare: GUS data for the years 1960-1986.

Graph 9. The employment structure in industrial plants with reference to their property structure in the years 1960-1985

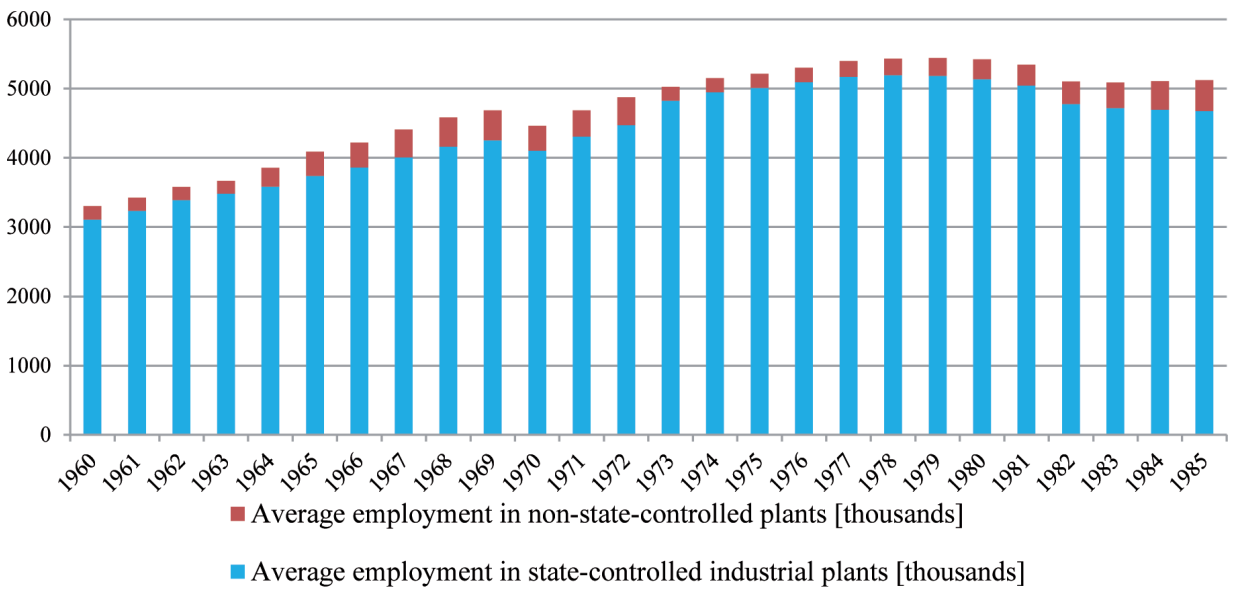

Source: own calculations. Compare: GUS data for the years 1960-1986.

sectors were prioritized. These situations were when the human nature and its character were tested, at least in the case of some social groups, both in the individual and collective dimension (coteries), and the results included e.g. economic scandals (e.g. the meat and leather scandals) [Majchrzak I. 1965: 305]. The situation of an individual changed in subse- 
Graph 10. Real income rate, cost of living of households and financial crime rate in social and economic understanding in the years 1955-1985

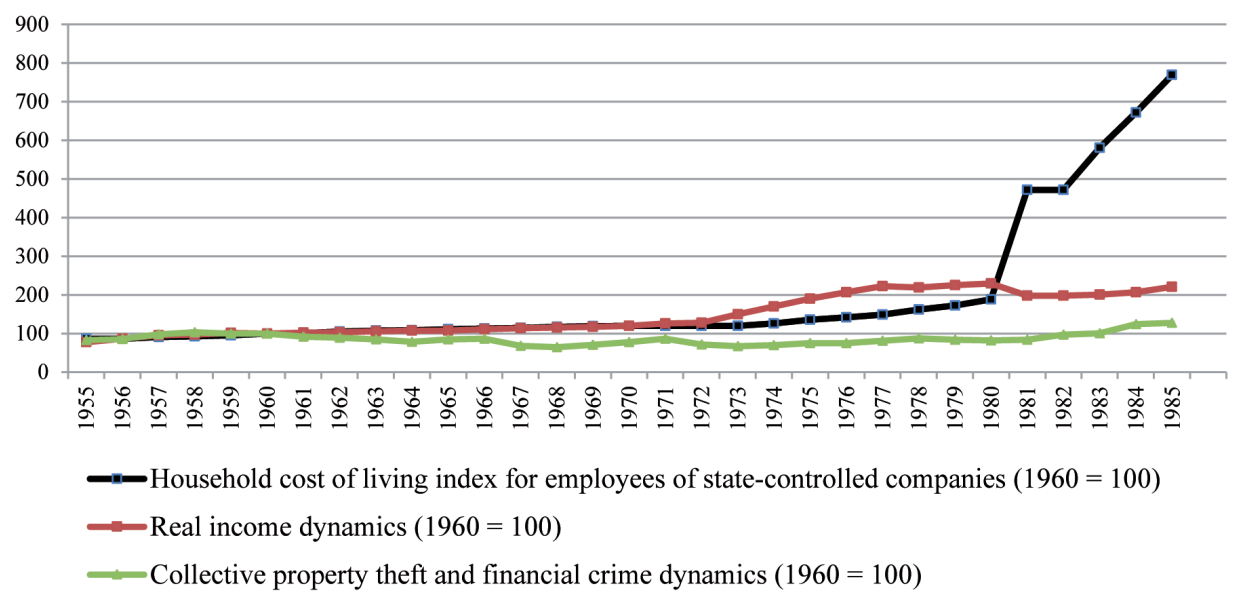

Source: own calculations. Compare: GUS data for the years 1955-1986.

quent decades of socialist Poland. A substantial group adapted to the everyday reality in every possible dimension. We will present this change by showing the cost of living rate, the dynamics of the real income, and the index of changes in the field of financial crime in the social and economic understanding (all the data were adjusted to the value for the year 1960). In the period analyzed, the real income dynamics rate in 1955 was $77 \%$ of the income achieved by families in 1960. In the last year studied, it grew to $220 \%$. This meant that the real income of households grew by almost $150 \mathrm{pp}$. At the same time, the cost of living rate was 87\% (1955) and 769\% (1985), respectively. Over 31 years, the cost of living grew by 682 pp., i.e. four times faster than the real income. Particularly after 1972 the annual increases of both factors were more dynamic. Considering the fact that the level of savings in the beginning of the period studied, due to the country's reconstruction, could not be high, this begs a purely economic question: how could these families support themselves by legal means?

When contrasted with that, the dynamics of changes in financial crime in a broader sense - not just in accordance with the legal definition but including (depending on the period studied) the aforementioned crimes to the harm of economic interests of the state, clerical offenses, fraud, documents-related crimes, and of course crimes against social property, look quite "decent". In the year 1955, the level of financial crime in this respect was $83 \%$ of the level from 1960. In 1985, it grew to $128 \%$. Among the three 
factors compared, the crime rate was characterized by the smallest dynamics. Of course, some factors that we did not analyze in detail could also affect the final result, e.g. crime detection rate, social permission, or the need for qualitative rather that quantitative analysis. However, taking into consideration the aforementioned limitations, it seems that in the conditions of the time the society fell victim to this trend to a smaller extent than the economic standing of households would suggest.

\section{SUMMARY AND CONCLUSIONS}

It seems fundamental to understand the nature of financial crime in the conditions of a system which proclaimed equality and justice for all. As we know, this concept failed at some point, whether as a result of the complexity of the human nature of the society, which for the most part rejected this "brave new world" and also in part entered the criminal path, or perhaps, as we also pointed out, as a consequence of some systemic characteristics of the socialist economic model itself. A hope for change was seen in "working on the essence of human nature". In order to prevent negative behaviors, it was necessary to implement a "system of organizational and supervisory activities, as long as they are aimed at preventing crime" [Lernell L. 1965: 7]. A chance was just a particular situation which prompted one to commit these, often unplanned, crimes.

It is very hard to come up with a consistent and versatile method of studying financial crime, though. Nonetheless, the available statistics allow us to gain some insight as to its scale in at least two dimensions: human - by documenting the convicts and victims, and economic - by documenting the size of financial and quantitative losses [Lernell L. 1965: 84]. A popular saying from the time - "There are no thieves, but people steal" - can perhaps summarize this incomplete analysis of the statistics available in the yearbooks of GUS. It was hard to define the scale of this type of crime, as its subjective assessment was subject to relative interpretations [Kalecki M. 1962: 74].

The GUS data allow us to analyze the problem of financial crime in socialist Poland, and in most cases, the results can be related to the political and economic situation of the country at the time. Financial crime in a broader understanding (as the classifications changed over time) accounted, depending on the year analyzed, for between $30 \%$ and $40 \%$ of the 
proceedings initiated. Convictions in these cases, in the years 1955-1985, comprised from $20 \%$ to $30 \%$ of all prison sentences. The number of proceedings initiated in cases of financial crime was relatively high in comparison to other crimes. However, the efficiency of these investigations measured by the number of convictions was, in relation to the broadly understood financial crime, at a similar level as that of other investigations. Only the average number of proceedings in cases of crimes against collective property was higher than the average.

The data presented here were shown through the lenses of the subsequent decades, starting from the year 1955. E.g. data from the 1970s (19701979) show that the financial crime rate was 10.2 of the total crime in the country, while the number of convicts was around 16,000 people annually until 1974, and then grew to around 18,000. [Górniok O. 1986: 17-18]. This can only indirectly point to the scale of the problem, but it is commonly known that the vast majority of perpetrators managed to avoid punishment, and that essentially this was due to a number of factors: the society's attitude to social property, its attitude (often very tolerant) to any crime witnessed, and the role of environmental factors. Our analysis lacks the breakdown of convicts according to age and gender, but despite the fact that such comparison are available, they are more significant for judicial and cultural reflections than for economic analysis.

Apart from the statistical analyses, we also attempted to explain the causes for the prevalence of financial crime in socialist Poland in the context of e.g. the political system. Many actions of the authorities, conducted in many fields in the post-war period, became a clear signal (at least for some part of the post-war society) that when it comes to property and money, one can commit subjective acts of appropriation. The economic model, seen as imposed by at least some parts of society or adopted in a passive way by others, showed an increasing imbalance between supply and demand. In our preliminary analysis, we avoid value judgments on the issue and the efficiency of methods aiming at preventing and fighting the problem of financial crime. We also do not intend to formulate any judgment on the authorities, society, administration, party and economic apparatus - we just wanted to point to general cultural conditions.

In general, two conclusions can be drawn from the studies of this subject concerning socialist Poland. First of all, in the population of those convicted for economic crimes, people aged 30 and over dominated. Secondly, the participation of women in this type of crime was higher than in other categories. Attempts to explain these trends undertaken so far, either 
based on the phenomenon of white collar crime or on the domination of women due to lack of violence involved [Górniok O. 1986: 103], are justified in some way, but in the context of the data used here, they remain outside of the scope of the study. The statistical data and the correlations resulting from them likely illustrate just a part of the problem of financial crime. Also the common awareness of the existence of an unknown number of undetected financial crimes - including black market operations or individuals who, as a result of a "low social harm" ruling, were not punished - makes any similar statistical data fit mainly for documentation purposes. The extent to which analyzing this problem in various cause and effect contexts or through interdisciplinary studies changes our perception of it remains unknown, but the aforementioned model shows the connection points at which financial crimes were committed.

It seems that the advantage of economic factors over the cultural ones in these analyses is indisputable e.g. due to the possibility of quantitative measurement and systematization; however, in the case of a society declaring deep religious belief, we witnessed a breach one of its commandments, namely "Thou shalt not steal". This does not mean that the latter do not matter and should not be taken into consideration when the society defined their individual aspirations, confronting them with e.g. the real level of income, the current economic potential of the country (on micro and macro levels) or the consumption patterns. The classification developed as a part of GUS statistics ignored (deliberately or not - but this is not the concern of this analysis) something that was indirectly indicated by a few papers in the 1980s. Categories such as "take", "favor", "odd job", "arrange" and "organize" replaced terms such as "buy", "sell", "service" or "trade", and were directly associated with acting to the harm of the socialist economy [Chłopecki J., Firlit E. 1987: 7-10]. It was nothing unusual, as it had already been noted among lawyers that financial crime was not universally viewed negatively [Cyprian T. 1960: 6].

The "3 Cs" model proposal presented in the form of a simplified diagram is an attempt to demonstrate the general mechanism of committing crime against property where:

- the object of the crime was an "attack" on the property in its two basic dimensions: social and private, and the negative result was the irrational use of the means of production, which e.g. indirectly influenced their final efficiency;

- the potential subjects of the crime were individuals or groups, operating independently or in "coteries", which we defined under 
the names of various institutional forms operating in the period described;

The scheme above includes the three variables defined here: circumstance (1), chance (2), and character (3), which can be formulated for the specific social and economic model by the definition of property as crucial for specifying the exact economic model. The system of interrelations between institutions allows us to see opportunities which can contribute to the decision to commit a crime, and in the end, there is an individual, who is both the emanation of the social relations and cultural influences, and their creator.

Finally, we would like to point to the subject interested in documenting financial crime, which was recorded for statistical purposes by entities that did not usually cooperate: Citizens' Militia Main Headquarter, General Prosecutor's Office and the Ministry of Justice, but also: the Supreme Audits Office, the Main Control and Supervision Inspection Office of the Ministry of Finance, and the Institute of Internal Trade. The reporting system (from the lowest level of particular companies, through associations, all the way up to relevant ministries) also played a role, and it should come as no surprise that statistics on the subject have so many gaps. Jacek Marecki, who in the 1960s started studying the problem as a part of the Polish Academy of Sciences' Committee for Studying Social Problems in Socialist Poland, headed by Michał Kalecki, pointed to the problems resulting from this dispersion when assessing the size of financial crime. In conclusion, we should also signal that regardless of the adopted methods of documenting this crime and its types, one more variable has a significant influence on the statistics, namely the detection rate - but this problem was excluded from our analysis.

\section{BIBLIOGRAPHY:}

PRINTED RESOURCES

Journal of Laws, 1932, no. 50, item 571 - The criminal code: presidential regulation of July $11,1932$.

Journal of Laws, 1952 no. 33, item 232 - The Constitution of the Polish People's Republic of July 22, 1952.

Journal of Laws, 1969, no. 13, item 94 - The criminal code: the Act of April 19, 1969.

\section{LITERATURE}

Bednarski M. (1992), Drugi obieg gospodarczy. Przestanki, mechanizmy i skutki w Polsce lat osiemdziesiatych [The parallel economy. Causes, mechanisms and results in Poland in the 1980s], Wydawnictwo Uniwersytetu Warszawskiego, Warsaw. 
Chłopecki J., Firlit E. (1987), Kiedy kradzież nie jest kradzieżą [When a theft is not a theft], "Zdanie" no. 3, p. 6-11.

Cyprian T. (1958), Próba określenia przestępstwa gospodarczego: pojęcie całości stosunków gospodarczych [An attempt to define financial crime: understanding all economic relations] "Ruch Prawniczy i Ekonomiczny" vol. 3, p. 17-29.

Cyprian T. (1960), Przestępstwa gospodarcze [Financial crime], Warsaw 1960.

Cyprian T. (1958), Próba określenia przestępstwa gospodarczego: pojęcie całości stosunków gospodarczych [An attempt to define financial crime: understanding all economic relations] "Ruch Prawniczy i Ekonomiczny" vol. 3, p. 17-29.

Górniok O. (1986), Przestępczość gospodarcza: wybrane przejawy i uwarunkowania [Financial crime: selected symptoms and conditions], Katowice.

Kalecki M. (1962), Próba wyjaśnienia zjawiska przestępczości gospodarczej [An attempt to explain the problem of financial crime], "Kultura i Społeczeństwo" no. 3, p. 73-77.

Lernell L. (1965), Przestępczość gospodarcza: zagadnienia społeczno-ekonomiczne [Financial crime: social and economic issues], Warsaw.

Majchrzak I. (1966), Pracownicze przestepstwo gospodarcze i jego sprawca [Financial crime of employees and its perpetrators], Warsaw.

Majchrzak I. (1965), Przestęstwo w zakładzie pracy [Crime in the workplace] [in]: "Socjologiczne problemy przedsiębiorstwa przemysłowego" [Sociological problems of industrial plants] (ed.) A. Sarapata, Warsaw.

Marecki J. (1962), Przestępczość gospodarcza: mechanizm i środki zaradcze [Financial crime: the mechanism and preventive measures], “Kultura i Społeczeństwo” vol. 3, p. 57-72.

Narojek W. (1973), Społeczeństwo planujące. Próba socjologii gospodarki socjalistycznej [The planning society. A sociological attempt to define socialist economy], Warsaw.

Pawełko W. (1971), Zapobieganie przestępstwom gospodarczym [Preventing financial crime], Warsaw.

Świda W. (1960), Wptyw zmiany ustroju na przestępczość [The influence of systemic transformation on crime], Wrocław.

Tymiński M. (2002), Malwersacje w przedsiębiorstwach socjalistycznych w Polsce (1950-1970) [Fraud in socialist companies in Poland (1950-1970)], "Dzieje Najnowsze", no. 4, p. 97113.

Tymowski A. (1977), Struktury społeczne - nowe aspekty badań [Social structures - new aspects of research], "Odra", no. 6.

Wyka K. (1984), Życie na niby. Pamiętnik po klęsce [Fake life. Life after the defeat], Kraków.

Lucyna Błażejczyk-Majka - PhD in economics, lecturer at the Department of Economic History in the Institute of History, the Adam Mickiewicz University. Her scientific interests include quatitative methods in economic studies, particularly concerning EU agriculture.

Roman Macyra - PhD, Professor of History at the Department of Economic History, the Adam Mickiewicz University. Scientific interests include the economic history and relationships with between different models of economics with the use of quantitative methods in history. 